\title{
Anemia and associated factors among school-age children in Filtu Town, Somali region, Southeast Ethiopia
}

\author{
Bekele Gutema ${ }^{1 \dagger}$, Wondimagegn Adissu $^{2}$, Yaregal Asress ${ }^{2}$ and Lealem Gedefaw ${ }^{2^{*}}$
}

\begin{abstract}
Background: Anemia is one of the major public health problems affecting more than half of school-age children in developing countries. Anemia among children has been conclusively seen to delay psychomotor development, poor cognitive performance, impaired immunity and decrease working capacity. The purpose of this study is to determine the prevalence and associated factors of anemia among school-age children in Filtu Town, Somali region, Southeast Ethiopia.
\end{abstract}

Methods: A community based cross-sectional study was conducted from July to August, 2013 in Filtu Town. A total of 355 school-age children between 5-15 years old were included in the study. Socio-demographic data were obtained from each participant using structured questionnaire. Hemoglobin concentration was determined by HemoCue $201^{+}$photometer (HemoCue, Angelholm, Sweden) analyzer. Hemoglobin values below $11.5 \mathrm{~g} / \mathrm{dl}$ and $12 \mathrm{~g} / \mathrm{dl}$ were considered as anemic for age ranges of 5-11 and 12-15 years, respectively. Anthropometric data were taken from each study participant. Peripheral blood film and stool examination were done for hemoparasite and intestinal parasite screening, respectively. Data were analyzed using SPSS version 16.0.

Results: Over all, prevalence of anemia was found to be $23.66 \%$. The vast majority (73.81\%) of the anemic children had mild anemia. Moderate and severe anemia accounted for $25 \%$ and $1.19 \%$ of the anemic children, respectively. Being from a family with low income ( $A O R=9.44,95 \% \mathrm{Cl}: 2.88,30.99)$, stunted ( $\mathrm{AOR}=5.50,95 \% \mathrm{Cl}: 2.83,10.72$ ), underweight ( $\mathrm{AOR}=2.07,95 \% \mathrm{Cl}: 1.06,4.05)$ and having intestinal parasite infection ( $\mathrm{AOR}=2.99,95 \% \mathrm{Cl}: 1.05,8.46)$ were identified as associated factors for anemia.

Conclusion: Anemia is a moderate public health problem in school-age children for the study area. Interventions targeting nutritional deficiencies and parasitic infections are recommended.

Keywords: Anemia, Associated factors, School-age children, Somali region

\section{Background}

Anemia is a condition which results from a reduction in hemoglobin concentration or reduction in red blood cell number or both resulting in lower ability of oxygen delivery to support the body's activities. Anemia is a public health problem in developing countries among school-age children. The highest prevalence of anemia exists in the developing world where its causes are multi-factorial. In the developing world, the prevalence among school-age

\footnotetext{
* Correspondence: lealem.gedefaw@ju.edu.et

${ }^{\dagger}$ Equal contributors

${ }^{2}$ Department of Medical Laboratory Science and Pathology, College of Public Health and Medical Sciences, Jimma University, Jimma, Ethiopia

Full list of author information is available at the end of the article
}

children ranges from 12-60\% [1-3]. Although the national level prevalence of anemia in Ethiopia is considered to be mild (with prevalence of 5-19.9\%), some regions exhibited high prevalence of anemia. According to the Ethiopian demographic and health survey report for the year 2005 and 2011, unlike most regions in the country, Somali region did not show a significant decline in the prevalence of anemia in the previous five years $[4,5]$.

Anemia in children may resulted from poor bioavailability of iron, infections like intestinal parasites, malaria and tuberculosis (TB). Although anemia has a variety of causes, it is generally assumed that $50 \%$ of cases are caused by iron deficiency. The main risk factors for iron deficiency among 
young children in developing countries are malnutrition (low intake) and high requirement of iron during child growth. Due to the multifactorial conditions, complexity of risk factors of anemia and potential interactions among them, a single strategy to control anemia in developing countries may have little success. An integrated strategy for anemia control and prevention is required [1,6-11].

Anemia is one of the most widespread public health problems, especially in developing countries with greater risk in schoolage children. Anemia in schoolage children result in lowered resistance to disease, increased susceptibility to infection, poor cognitive development, impaired physical development, poor school performance and reduced work capacity with impaired social and economic development of the country $[12,13]$.

In Ethiopia, studies on anemia often focus in pregnant women and under five years of age children. There are limited data on anemia in school-aged children and predisposing factors. Hence this this study is conducted to determine the magnitude of anemia and its associated factors among school-age children in Filtu Town, Somali Region of South-East Ethiopia.

\section{Methods}

\section{Study setting and sampling}

A community based cross sectional study was conducted from July to August 2013 in Filtu Town. The town is in Ethio-Somali region, South East Ethiopia. 355 school-age children were determined using single population proportion statistical formula by the following assumptions: $95 \%$ level of confidence, 5\% margin of error and P (proportion) of 0.3 taken from a study done in neighboring Somalia [14]. Systematic sampling technique was applied by using house number as sampling frame obtained from Filtu Town health extension workers office. The town has three kebeles, the smallest administration unit in the country, named as: 01,02 and 03 with the total household of 295, 209 and 197, respectively. First, the total sample size was proportionally allocated to the three kebeles. Then, proportionally allocated numbers of households were selected by systematic random sampling method from each Kebele. Finally, from one systematically selected house hold, one school-age children was recruited. Simple random sampling technique was used when more than one eligible children found in a single household whereas the next household was considered when there was no eligible child in the systematically selected household. School-aged children between 5-15 years old were included in the study whereas those children on treatment of anemia, and children with chronic disease were excluded from the study.

\section{Data collection and processing}

Socio-demographic, socioeconomic and other related data were collected by questionnaire based interview.
Hemoglobin ( $\mathrm{Hgb}$ ) concentration was determined by Hemo Cue HB $201^{+}$analyzer (Hemo Cue, Angelholm, Sweden) from capillary blood sample. Capillary blood was collected by finger pricking after rubbing the fingertip with sterile cotton (immersed in $70 \%$ alcohol), and pricking it with a sterile disposable lancet. A drop of blood was allowed to enter the optical window of the microcuvette through capillary action after discharging the first drop of blood. Then microcuvette was placed into the cuvette holder for photometric determination of hemoglobin level.

School-age children with Hgb levels lower than $11.5 \mathrm{~g} / \mathrm{dl}$ and $12 \mathrm{~g} / \mathrm{dl}$ was considered as anemic for age ranges from 5-11 and 12-15 years old, respectively. Mild anemia was defined as Hgb concentration of 10-11.9 g/dl for 12-15 years and Hgb concentration of 10-11.4 $\mathrm{g} / \mathrm{dl}$ for 5-11 years. Moderate anemia was defined as $\mathrm{Hgb}$ concentration between 7-9.9 $\mathrm{g} / \mathrm{dl}$ and severe anemia was defined as $\mathrm{Hgb}$ concentration lower than $7 \mathrm{~g} / \mathrm{dl}$ [1]. Both thick and thin blood films were prepared and stained for the assessment of hemoparasites. Five $(5 \mathrm{gm})$ of stool samples were collected from each study participant using clean and leakproof stool cups. Stool samples were examined using both direct wet mount method and formol-ether concentration technique.

Weights were measured with children in light clothing using a portable digital scale to the nearest $0.1 \mathrm{~kg}$. Calibrated, fixed base portable wooden scale was used for height measurement to the nearest $0.1 \mathrm{~cm}$. Every measurement was performed three times, and the mean values were used for analysis. All the data were transformed and expressed in Z-scores and calculated using WHO anthroPlus1.0.4 statistical software packages for ages 5-19 years. The mean $\mathrm{Z}$ scores were calculated and under nutrition was defined for a child, who has less than -2 z-scores $(-2 S D)$ from the National center for health statistics (NCHS) median reference population values. This was used as cut-off points for determination of malnourishment.

To assure the quality of data one day training was given for data collectors and daily supervision was made during the data collection period. Standard operating procedures (SOPs) and manufacturers' instruction were strictly followed for all laboratory activities. All laboratory reagents were checked for their expiry date. Laboratory results were recorded on standard report formats using participants' identification number.

\section{Data analysis}

Data were coded, cleaned prior to analysis, entered and analyzed using SPSS V16.0 statistical software. Description statistics (mean, frequencies, cross tabulation) were done to describe the study participants and determine the prevalence of anemia. Bivariate and multivariate 
logistic regression analyses were done to look for statistically significant associated factors of anemia. For the logistic regression analysis, initially we have observed the association of each independent variable with the dependent variable. Those variables with $\mathrm{P}$ value of 0.25 or less in the bivariate logistic regression and other variables with $\mathrm{P}$ value $>0.25$ but having scientifically proved public health importance were our candidate variables for the multivariate logistic regression model. Finally, variables having $\mathrm{P}$ value of 0.05 or less were taken statistically significant factors for anemia.

\section{Ethical approval and consent}

Ethical clearance was obtained from Jimma University ethical review board and permission was taken from Filtu district health bureau to conduct the study. Written informed consent was obtained from the parents/ guardians. Moreover, assent portion of consent form for children greater than 7 years old were prepared and obtained. All the study participants who were found positive for intestinal, hemoparasites and anemia were treated free of charge at Filtu district hospital, Somali region southeast Ethiopia.

\section{Results}

Socio-demographic characteristics of study participants A total of 355 school-age children $(52.68 \%$ male were male and $47.32 \%$ female) had participated in the study. Majority of study participants, 289 (81.41\%) were within the age group of 5-11 years with mean age of $8.51 \pm$ 2.83 years. Most of the children's mothers $(79.15 \%)$ and fathers $(67.32 \%)$ were illiterate (Table 1$)$.

\section{Nutritional status and clinical characteristics of study participants}

Out of all the study participants, 117 (32.96\%) of them were stunted for their age, and 104 (29.30\%) were underweight. Eighty one (22.82\%) of the children were positive for intestinal parasites. A total of seven species of intestinal parasites were identified. Ascaris lumbricoides (43.21\%) was predominant followed by Giardia lamblia (22.22\%), Hook worms (12.35\%), Trichuris trichiuria 8 (9.88\%), Enterobius vermicularis 4 (4.94\%), Hymenolepis nana 3 (3.70\%) and Entamoeba histolytica/dispar 3 (3.70\%). Microscopic examination of the blood films revealed $13(3.66 \%)$ malaria cases (Table 2$)$.

\section{Prevalence of anemia}

Overall, prevalence of anemia among school-aged children was $23.66 \%$. Most of the anemic children (73.81\%) had mild anemia. Moderate and severe anemia accounted for $25.00 \%$ and $1.19 \%$ of the cases. The prevalence was higher in males $(27.81 \%)$ than the female $(19.05 \%)$ children. Hemoglobin level of children ranged from 6.70 to
$15.30 \mathrm{~g} / \mathrm{dl}$ with mean of $12.43 \pm 1.42 \mathrm{~g} / \mathrm{dl}$. Anemia prevalence was $25.95 \%$ among the age group 5-11 years old and $13.64 \%$ among $12-15$ years age groups. Anemia among children whose mothers were housewives was 59 (27.19\%) (Table 1).

The prevalence of anemia among stunted study participants was 55 (47.01\%). Seven of the children with malaria $(53.85 \%)$ and $41.98 \%$ of the children with intestinal parasitic infection were anemic (Table 2).

\section{Factors associated with anemia}

All explanatory variables with $P$ value of $\leq 0.25$ on bivariate analysis were entered into the multivariate logistic regression models to identify independently associated factors with anemia. Accordingly, monthly household income, stunting, underweight and intestinal parasitic infection were identified independent associated factors of anemia (Table 3).

Regarding monthly household income, after controlling confounding effect the odds of being anemic among children whose families monthly income $<500$ Ethiopian Birr were 9.44 times higher than among children whose families monthly income $>2000$ Ethiopian Birr (AOR = 9.44, 95\% CI: 2.88-30.99). The odds of being anemic were 5.50 times higher among stunted children than those non stunted children $(\mathrm{AOR}=5.50,95 \% \mathrm{CI}: 2.83$, 10.72). Underweight school-aged children were 2.07 times more likely to be anemic compared to normal children $(\mathrm{AOR}=2.07,95 \% \mathrm{CI}: 1.06,4.05)$. Infection with intestinal parasite increase the likelihood of anemia by 2.99 times as compared to non- infected children $(\mathrm{AOR}=2.99,95 \% \mathrm{CI}$ : 1.05, 849) (Table 3).

\section{Discussions}

The overall prevalence of anemia among school-aged children was $23.66 \%$, suggesting that anemia is a public health problem among the school-aged children in the area. No similar study was obtained to compare our finding with; however, $11 \%$ prevalence was reported from Northern part of Ethiopia [15]. The larger regional variation might be due to differences in geographical variation and differences in life style.

The prevalence of anemia in our study is higher than those similar studies reported from different areas like, Egyptian children 12\% [16], among school-age children in Kenitra Morocco 12.2\% [17] and among Sanliurfa, South-east Turkish children 5.4\% [18]. This variation might be due to low socioeconomic status and lower nutritional status of school-aged children in this study area than those reported from elsewhere. For instance a study in Kenitra Morocco indicated that only 8.9\% (26/293) and $12.6 \%(37 / 293)$ were stunted and underweight, respectively which is lower than our study where 117 $(32.96 \%)$ of school-age children were stunted for their 
Table 1 Associations of anemia with Socio-demographic characteristics among school-age children in Filtu Town, Somali region, South-East Ethiopia, 2013 ( $n=355$ )

\begin{tabular}{|c|c|c|c|c|c|}
\hline \multirow[t]{2}{*}{ Variables } & \multirow[t]{2}{*}{ Categories } & \multicolumn{2}{|l|}{ Anemia } & \multirow[t]{2}{*}{$\operatorname{COR}^{*}(95 \% \mathrm{Cl})$} & \multirow[t]{2}{*}{ P-value } \\
\hline & & Yes (\%) & No (\%) & & \\
\hline \multirow[t]{2}{*}{ Sex } & Male & $52(27.81)$ & $135(72.19)$ & $\operatorname{Ref}(1)$ & \\
\hline & Female & $32(19.05)$ & $136(81.95)$ & $0.61(0.30,1.01)$ & 0.054 \\
\hline \multirow[t]{2}{*}{ Age } & $5-11$ & $75(25.95)$ & $214(74.05)$ & $2.20(1.05,4.70)$ & 0.037 \\
\hline & $12-15$ & $9(13.64)$ & $57(86.36)$ & $\operatorname{Ref}(1)$ & \\
\hline \multirow[t]{6}{*}{ Mother's occupations } & House wife & $59(27.19)$ & $158(72.81)$ & $\operatorname{Ref}(1)$ & \\
\hline & Merchant & $10(14.49)$ & $59(85.51)$ & $0.7(0.28,1.77)$ & 0.461 \\
\hline & Governmental employee & $3(10.34)$ & $26(89.66)$ & $0.5(0.10,2.61)$ & 0.413 \\
\hline & Private employee & $3(25.00)$ & $9(75.00)$ & $0.9(0.13,5.22)$ & 0.849 \\
\hline & Daily laborer & $6(31.58)$ & $13(68.42)$ & $1.5(0.44,5.15)$ & 0.508 \\
\hline & No job & $3(33.33)$ & $6(66.67)$ & $0.9(0.13,6.87)$ & 0.941 \\
\hline \multirow[t]{6}{*}{ Father's occupation } & Farmer /pastoralist & $28(36.36)$ & $49(63.64)$ & $\operatorname{Ref}(1)$ & \\
\hline & Merchant & $11(17.74)$ & $51(82.26)$ & $0.38(0.17,0.84)$ & 0.017 \\
\hline & Governmental employee & $9(13.64)$ & $57(86.36)$ & $0.28(0.12,0.64)$ & 0.003 \\
\hline & Private employee & $7(17.50)$ & $33(82.50)$ & $0.37(0.15,0.95)$ & 0.038 \\
\hline & Daily laborer & $20(24.10)$ & $63(75.90)$ & $0.56(0.28,1.10)$ & 0.092 \\
\hline & No job & $9(33.33)$ & $18(66.67)$ & $0.88(0.35,2.21)$ & 0.777 \\
\hline \multirow[t]{4}{*}{ Mother's education } & Illiterate & $76(27.05)$ & $205(72.95)$ & $7.4(0.98,56.20)$ & 0.053 \\
\hline & Primary school & $5(13.89)$ & $31(86.11)$ & $3.2(0.35,29.68)$ & 0.301 \\
\hline & High school & $2(11.76)$ & $15(88.24)$ & $2.7(0.22,32.23)$ & 0.440 \\
\hline & Collage or above & $1(4.76)$ & $20(95.24)$ & $\operatorname{Ref}(1)$ & \\
\hline \multirow[t]{4}{*}{ Father's education } & Illiterate & $64(26.78)$ & $175(73.22)$ & $1.9(0.86,4.31)$ & 0.114 \\
\hline & Primary school & $10(24.39)$ & $31(75.61)$ & $1.7(0.56,4.79)$ & 0.320 \\
\hline & High school & $2(8.00)$ & $23(92.00)$ & $0.5(0.09,2.33)$ & 0.346 \\
\hline & Collage or above & $8(16.00)$ & $42(84.00)$ & $\operatorname{Ref}(1)$ & \\
\hline \multirow[t]{3}{*}{ Monthly household income } & $<500 \mathrm{ETB}^{*}$ & $11(50.00)$ & $11(50.00)$ & $8.90(3.43,23.13)$ & $<0.001$ \\
\hline & 500-1999 ETB & $53(39.26)$ & $82(60.74)$ & $5.75(3.23,10.30)$ & $<0.001$ \\
\hline & $\geq 2000$ ETB & $20(10.10)$ & $178(89.90)$ & $\operatorname{Ref}(1)$ & \\
\hline \multirow[t]{2}{*}{ Family size } & $<5$ & $8(9.20)$ & $79(90.80)$ & $0.26(0.12,0.56)$ & 0.001 \\
\hline & $\geq 5$ & 76 (28.36) & 192 (71.64) & $\operatorname{Ref}(1)$ & \\
\hline
\end{tabular}

NB: $E^{*} B^{*}=$ Ethiopian Birr.

age, and 104 (29.30\%) were underweight. In addition, majority of our study participants had 5 or more family members which has an effect on their quality of life.

However, prevalence of anemia in our study is much lower than similar reports conducted in Tanzania (79.6\%) [19], in Kenya (35.3\%) [20], in Abia State, Nigeria (82.6\%) [21]. The lower prevalence of anemia in our study might be due to the fact that malaria which is one of the major causes of anemia was less prevalent (3.66\%) in this study compared to the previous studies. A study in Nigeria reported that malaria parasite, which, may also contribute to the etiology, and severity of anemia through several mechanisms including destruction of red blood cells, was confirmed in majority of the children (93.2\%) with Plasmodium falciparum as the primary cause of severe malaria (39.8\%). Moreover, the prevalence of hookworm infection in our study is low and shistosomiasis is not detected, which are major causes of anemia but they were the major causes of anemia in Tanzania and Kenya [19,20].

The prevalence of anemia changed according to sociodemographic characteristics of children and their families which showed statistically significant differences for some variables and not for others. Children from families with low monthly household income were more likely to be anemic than those children from families with high monthly house hold income $(\mathrm{AOR}=9.44,95 \%$ 
Table 2 Associations of anemia with nutritional status and clinical characteristics among school-age children in Filtu Town Somali region, South- East Ethiopia, $2013(n=355)$

\begin{tabular}{|c|c|c|c|c|c|}
\hline \multirow[t]{2}{*}{ Variables } & \multirow[t]{2}{*}{ categories } & \multicolumn{2}{|c|}{ Anemia } & \multirow[t]{2}{*}{ COR $^{*}(95 \% \mathrm{Cl})$} & \multirow[t]{2}{*}{ P-value } \\
\hline & & Yes (\%) & No (\%) & & \\
\hline \multirow[t]{2}{*}{ Stunting (Z score $<-2 \mathrm{SD}^{*}$ ) } & Yes & $55(47.01)$ & $62(52.99)$ & $6.39(3.76,10.88)$ & $<0.0001$ \\
\hline & No & $29(12.18)$ & $209(87.82)$ & $\operatorname{Ref}(1)$ & \\
\hline \multirow[t]{2}{*}{ Underweight (Z score < - 2SD) } & Yes & $43(41.35)$ & $61(58.65)$ & $3.16(2.16,6.01)$ & $<0.0001$ \\
\hline & No & $41(16.33)$ & $210(83.67)$ & $\operatorname{Ref}(1)$ & \\
\hline \multirow[t]{2}{*}{ Intestinal parasite infection } & Positive & $34(41.98)$ & $47(58.02)$ & $2.49(1.14,5.45)$ & 0.023 \\
\hline & Negative & $60(21.89)$ & $214(78.11)$ & $\operatorname{Ref}(1)$ & \\
\hline \multirow[t]{2}{*}{ Malaria } & Positive & $7(53.85)$ & $6(46.15)$ & $4.02(1.31,12.30)$ & 0.015 \\
\hline & Negative & $77(22.51)$ & $265(77.49)$ & $\operatorname{Ref}(1)$ & \\
\hline
\end{tabular}

$\mathrm{COR}^{*}=$ Crude odds ratio, $S D^{*}=$ standard deviation.

CI: 2.88, 30.99). This might be due to the fact that families with low monthly household income may not get enough iron-rich foods and diets of children living in poor families are usually monotonous. This is similar with the study conducted among students of Ningxia and Qinghai's poor counties of rural China's [22].

Stunted children are 5.50 times more likely to be anemic than non-stunted children $(\mathrm{AOR}=5.50,95 \% \mathrm{CI}$ : $2.83,10.72$ ) and children who are underweight are 2.07 times more likely to be anemic than children with normal weight $(A O R=2.07,95 \% \mathrm{CI}: 1.06,4.05)$. This might be due to long term effect of low iron intake and other micronutrient deficiencies. It was supported by studies conducted in Tanzania [19] reported that under weight was significantly associated with anemia $(\mathrm{P}<0.05)$ by suggesting it could be diet related which is long term effect of low iron intake and Vitamin A deficiency among the children.

School-age children infected with intestinal parasites are more likely to be anemic than those none infected children (AOR $=2.99$, 95\% C.I: $1.05,8.49$ 6.73). This is similar with the studies reported from Tanzania [19] and the study from Edo state, Nigeria [23]. This might be due to the fact that most identified intestinal parasites have their own contribution on blood loss and/or red cell destruction.

Although literature indicates there is indeed a strong association of malaria with increased prevalence of anemia through several mechanisms including destruction of red blood cells [23], we did not find an association between anemia and malaria infection probably due to low prevalence of malaria in our study area, because the present study did not consider seasonal variation of malaria.

\section{Conclusion}

Anemia was moderate significant health problem among school-aged children with the overall prevalence of 23.66\%. Malnutrition and intestinal parasitic infection are the main associated factors of anemia among schoolage children. Therefore, further longitudinal studies with long term follow-up are needed to explore more on the causes of anemia among school-age children in resource limited settings for possible intervention.

Table 3 Multivariate logistic regressions of selected variables associated with anemia among school-age children in Filtu Town, Somali region, South- East Ethiopia, 2013

\begin{tabular}{|c|c|c|c|c|c|}
\hline Variables & Categories & $\operatorname{COR}^{*}\left(95 \% \mathrm{Cl}^{*}\right)$ & P-value & $\mathrm{AOR}^{*}(95 \% \mathrm{Cl})$ & P-value \\
\hline \multirow[t]{3}{*}{ Family income } & $<500$ & $8.90(3.43,23.13)$ & $<0.0001$ & $9.44(2.88,30.99)$ & $<0.0001$ \\
\hline & $500-1999$ & $5.75(3.23,10.88)$ & $<0.0001$ & $4.73(2.31,2.31)$ & $<0.0001$ \\
\hline & $>2000$ & $\operatorname{Ref}(1)$ & & Ref (1) & \\
\hline \multirow[t]{2}{*}{ Stunting (Z score < -2SD) } & Yes & $6.39(3.76,10.88)$ & $<0.0001$ & $5.50(2.83,10.72)$ & $<0.0001$ \\
\hline & No & $\operatorname{Ref}(1)$ & & Ref (1) & \\
\hline \multirow[t]{2}{*}{ Underweight (Z score $<-2 S D$ ) } & Yes & $3.16(2.16,6.01)$ & $<0.0001$ & $2.07(1.06,4.05)$ & 0.034 \\
\hline & No & $\operatorname{Ref}(1)$ & & Ref (1) & \\
\hline \multirow[t]{2}{*}{ Intestinal parasitic infection } & Positive & $2.49(1.14,5.45)$ & 0.023 & $2.99(1.05,8.49)$ & 0.040 \\
\hline & Negative & $\operatorname{Ref}(1)$ & & $\operatorname{Ref}(1)$ & \\
\hline
\end{tabular}




\section{Competing interest}

The authors declare that they have no competing interests.

\section{Authors' contribution}

BG and LG conceived the study, participated in the design and data analysis. WA and YA involved in data acquisition, laboratory work and drafted the manuscript. LG critically reviewed the manuscript. All authors read and approved the manuscript.

\section{Acknowledgment}

We would like to thank our data collectors for their invaluable effort. Our deep gratitude also goes to our study subjects who were volunteer and took their time to give us all the relevant information for the study.

\section{Author details}

'Department of Clinical Laboratory, Filtu District Hospital, Somali region, Somali, Ethiopia. 'Department of Medical Laboratory Science and Pathology, College of Public Health and Medical Sciences, Jimma University, Jimma, Ethiopia.

Received: 20 March 2014 Accepted: 13 August 2014 Published: 18 August 2014

\section{References}

1. World Health Organization/United Nations University/UNICEF: Iron deficiency anemia, assessment, prevention and control: a guide for programme managers. Geneva: WHO; 2001.

2. Administrative Committee on Coordination/Standing Committee on Nutrition, ACC/SCN: Fourth Report on the World Nutrition Situation. New York: United Nations; 2000.

3. Hall A, Bobrow E, Brooker S, Jukes M, Nokes K, Lambo J, Guyatt H, Bundy D, Adjei S, Wen ST, Satoto, Subagio H, Rafiluddin MZ, Miguel T, Moulin S, de Graft Johnson J, Mukaka M, Roschnik N, Sacko M, Zacher A, Mahumane B, Kihamia C, Mwanri L, Tatala S, Lwambo N, Siza J, Khanh LN, Khoi HH, Toan ND: Anemia in schoolchildren in eight countries in Africa and Asia. Public Health Nutr 2000, 4(3):749-756.

4. Ethiopia Central Statistical Agency and ICF Internationa: Ethiopia Demographic and Health Survey: Key Findings. Calverton, Maryland, USA: CSA and ICF International; 2012.

5. Ethiopia Central Statistical Agency: Ethiopia Demographic and Health Survey 2005; Preliminary Report. Addis Ababa Ethiopia: Central statistics agency; 2005.

6. Van Eijik AM, Ayisi JG, Terkuile FO: Malaria and human immunodeficiency virus infection as risk factor for anemia in infants in Kisumu, Western Kenya. Am J Trop Med Hyg 2002, 67(1):44-53.

7. World Health Organization, Centers for Disease Control and Prevention, Benoist B, McLean E, Egli I, Cogswell M (Eds): Worldwide prevalence of anemia 1993-2005. Geneva: World Health Organization; 2008.

8. Halterman JS, Kaczorowski JM, Aligne CA, Auinger P, Szilagyi PG: Iron deficiency and cognitive achievement among school-aged children and adolescents in the United States. Pediatrics 2001, 107(6):1381-1386.

9. Beard JL: Iron requirements in adolescent females. J Nutr 2000, 130(25 Supp I):440-442.

10. Dickson R, Awasthi S, Williamson P, Demellweek C, Garner P: Effects of treatment for intestinal helminthes infection on growth and cognitive performance in children: systematic review of randomized trials. $\mathrm{Br}$ Med $J$ 2000, 320:1697-1701.

11. Sharman A: Anemia Testing in Population-Based Surveys: Integrated Anemia Control and Prevention Strategy. Maryland, USA: ORC Macro Calverton; 2000.

12. Grantham-McGregor S, Ani C: A review of studies on the effect of iron deficiency on cognitive development in children. J Nutr 2001, 131(2):649-666.

13. Nokes C, van den Bosch C, Bundy DAP: The Effects of Iron Deficiency and Anemia on Mental and Motor Performance, Educational Achievement, and Behaviors in Children. An Annotated Bibliography. Washington, DC: INACG and ILSI Press; 1998.

14. Somali women and children at risk of anemia: Available at: http://somalidoc. com/smf/index.php/topic,4092.0/prev_next,next.html\#new. Accessed date Jun 13, 2013]

15. Mahmud MA, Spigt M, Mulugeta BA, Lopez PI, Dinant GJ, Blanco VR: Risk factors for intestinal parasitosis, anemia, and malnutrition among school children in Ethiopia. Pathog Glob Health 2013, 107(2):58-65.
16. Barduagni P, Ahmed AS, Curtale F, Raafat M, Mansour E: Anemia among school children in Qena Governorate, Upper Egypt. East Mediterr Health J 2004, 10(6):917-919.

17. El Hioui M, Ahami AO, Aboussaleh Y, Rusinek S, Dik K, Soualem A, Azzaoui FZ, Loutfi H, Elqaj M: Risk Factors of Anemia among rural school Children in Kenitra, Morocco. East Afr J of Public Health 2008, 5(2):62-66.

18. Koc A, Kosecik M, Vural H, Erel O, Atlas A, Tatli MM: The frequency and etiology of anemia among children 6-16 years of age in Sauth-east region of Turkey. Turk J Pediatr 2000, 42:91-95.

19. Tatala SR, Kihamia CM, Kyungu LH, Svanberg U: Risk factors for anemia in schoolchildren in Tanga Region, Tanzania. Tanzan J Health Res 2008, 10(4):189-201.

20. Pullan RL, Gitonga C, Mwandawiro C, Snow RW, Brooker S: Estimating the relative contribution of parasitic infections and nutrition for anemia among school-aged children in Kenya: a sub-national geostatistical analysis. BMJ Open 2013, 3:1-10.

21. Onimawo IA, Ukegbu PO, Asumugha VU, Anyaka JU, Okudu H, Echenda CA, Nkwoala C, Emebu P: Assessment of anemia and iron status of school-age children (aged 7-12 years) in rural communities of Abia state, Nigeria. AJFAND 2010, 10(5):2570-2585.

22. Luo R, Zhang L, Liu C, Zhao Q, Shi Y, Miller G, Elaine Y, Brian S, Alexis M, Scott R, Reynaldo M: Anemia in Rural China's Elementary Schools: Prevalence and Correlates in Ningxia and Qinghai's Poor Counties. $J$ Health Popul Nutr 2011, 29(5):471-485.

23. Osazuwa F, Ayo OM, Imade P: Contribution of malnutrition and malaria to anemia in children in rural communities of Edo state, Nigeria. N Am J Med Sci 2010, 2(1):532-536.

doi:10.1186/2052-1839-14-13

Cite this article as: Gutema et al:: Anemia and associated factors among school-age children in Filtu Town, Somali region, Southeast Ethiopia. BMC Hematology 2014 14:13.

\section{Submit your next manuscript to BioMed Central and take full advantage of:}

- Convenient online submission

- Thorough peer review

- No space constraints or color figure charges

- Immediate publication on acceptance

- Inclusion in PubMed, CAS, Scopus and Google Scholar

- Research which is freely available for redistribution

Submit your manuscript at www.biomedcentral.com/submit
C BioMed Central 